\title{
THE EPISTLE TO THE HEBREWS: FAITH MEANS PERSEVERANCE
}

\author{
P. H. ROB VAN HOUWELINGEN \\ THEOLOGICAL UNIVERSITY KAMPEN ${ }^{1}$
}

\begin{abstract}
In terms of lifestyle, the first Christians were, according to the New Testament, in constant interaction with their non-Christian environment. This was even so when that society responded critically or dismissively. How dynamic was the relationship between ethics and missionary aw areness? This article charts a biblical-theological quest through the Epistle to the Hebrews, a New Testament letter addressed to Jewish-Christian readers who should refocus their lives in a time of crisis. The writer of this letter urges them to look in faith to Jesus Christ, the superior high priest in heaven, this being a hint for future readers who al so desire to persevere in a time of crisis.
\end{abstract}

Keywords: Epistle to the Hebrews, Christian ethics, Jewish Christianity, mission, perseverance.

\section{INTRODUCTION}

The Epistle to the Hebrews has been referred to as the most enigmatic of all the writings of the N ew Testament. It ends like a letter, but it lacks the beginning typical of a letter. The author's name is absent, but he clearly has a good relationship with the readers, probably Jews ('Hebrews' according to the title) who accepted Jesus of Nazareth as the M essiah of Israel. He hopes to meet them personally (Heb. 13:23b). A nd yet, the community of believers is not identified or located in any way. This is all very puzzling indeed.

1 Dr P. H. R. (Rob) van Houwelingen is professor of $\mathrm{N}$ ew Testament at the Theological University K ampen, the N etherlands, as well as research associate of Prof. Dr. J. K ok (M ission and Ethics Project) in the Department of $\mathrm{N}$ ew Testament Studies, U niversity of Pretoria, South A frica. 
At the same time, there can be no doubt that the Epistle to the Hebrews is a text of great theological significance. This letter particularly discusses the function of the new covenant as a fulfilment of the earlier covenant relationship between the God of Israel and his people. Dealing with that important fulfilment, the author points to the reconciling work of Jesus Christ. His atoning sacrifice is a prerequisite for having communion with God in the new covenant. $\mathrm{H}$ is coming has introduced a new era. Only through his mediation, the broken relationship between $\mathrm{God}$ and his people is restored. Despite all the riddles surrounding the so-called introductory issues, the theological message of the Epistle to the Hebrews is clear. ${ }^{2}$

This article consists of three main parts. Firstly, the aim of the letter will be clarified by interpreting the situation in which the author appeals to his readers. Here the city of J erusalem takes central stage. J ewish belief sought salvation in J erusalem since there the holy temple was located. J esus-believing J ews, how ever, need to look elsewhere for their salvation. They must seek it in heaven, with J esus the M essiah. Second, a more detailed discussion will deal with the main focus of the letter: the theme of atonement by which Christ established reconciliation between God and man. The Epistle to the Hebrews extensively deals with bringing the true sacrifice for sin unto man's salvation. This atoning sacrifice for sin is in the letter exclusively associated with the heavenly high priest. Finally an important aspect of Christian life will be examined. That aspect concerns the dynamic interaction between ethics and mission in this letter. The change from the old covenant to the new covenant and the reconciling work of the heavenly priest had an impact on the readers' life and witness. The way in which they cope with the hard circumstances of their life as Christians will not remain unnoticed by nonChristian outsiders.

\section{AIM OF THE LETTER}

\subsection{The Temple as Marker}

Regarding the Epistle to the Hebrews the key question is whether the temple in Jerusalem was still in operation or not. In the letter, cultic worship is consistently described in verb forms that denote the continuing present. This usage may be no more than a literary convention (as for example, in a cultic passage in 1 Clem. 40-41). Hebrews, however, draws on existing cultic data when arguing that the readers are to seek their salvation in Christ who is in heaven. The writer argues, for instance, that the continuing sacrifices

2 This contribution contains material from: P. H. R. van Houwelingen, 'R iddles around the L etter to the Hebrews,' Fides Reformata 16/2 (2011): 151-162. In that article, the introductory issues are discussed in a more detailed way. Unless otherwise indicated, all biblical quotations and references are taken from the New International Version Bible (NIV), 1984 edition. 
can never make perfect those who draw near to worship. If they could, he says, would they not have stopped being offered (Heb. 10:1,2)? If he had written his letter after the fall of J erusalem and the destruction of the temple, he would have formulated his point differently. In other passages, too, it appears that at the time of writing this letter cultic worship in the temple was still alive and well (Heb. 7:27-28; 8:3-5; 9:25; 10:8; 13:10). For this reason it is a defensible position to situate this letter before the fall of $\mathrm{J}$ erusal em in 70 C.E. ${ }^{3}$ W hen a later date would be preferred, as often happens, the destruction of the temple still remains both for the writer and for his readers an essential marker of the recent past of Israel. The recipients of the letter were Jewish Christians whether from Jerusalem or from the Diaspora. They regarded the temple as their religious centre. The nullification of the temple sacrifices and ceremonies required a fundamental reorientation.

It is remarkable, though, that the writer nowhere refers explicitly to the temple. Instead, he continually goes back to the tabernacle (also called the Tent of M eeting) as the earthly sanctuary, and to the people of Israel during their time in the wilderness. He consistently portrays the cultic worship in J erusalem in Old Testament terms. Stephen similarly did so in his address (A cts 7), showing that the moveable tabernacle (a large tent) points to something that is transient. The reference to that earthly sanctuary probably was done to relativise the importance of the temple, and to warn the Jews against misplaced pride. The sanctuary in J erusalem is neither the beginning nor the end of meeting with God. If the old covenant of Sinai is described as obsolete and ageing ( $H$ eb. 8:13), then the cultic worship in the Old Testament is certainly included.

In his line of reasoning, the author of Hebrews goes back to the Old Testament system of the temple worship. By highlighting the mobility and the temporary character of the Tent of $M$ eeting, he makes his readers see that true and rather permanent worship has been moved to heaven. That is the worship of the God who spoke to Israel's forefathers (Heb. 1:1), finding its resting place and ultimate meaning in the person of J esus Christ, God's Son. ${ }^{4}$

\subsection{A Word of Exhortation}

The J ewish Christians were severely oppressed by their nationalist compatriots. They

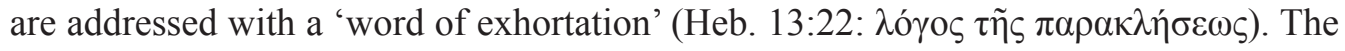
fact that the letter identifies itself in this way seems also to describe its character. Acts

3 E.g. by D. A. Carson and D. J. M 00, An Introduction to the New Testament (2d. ed.; Leicester: Apollos, 2005), 606-607; P. W. L. Walker, J esus and the H oly City: New Testament P erspectives on J erusalem (Grand Rapids: Eerdmans, 1996), 227-230.

4 B. F. Westcott, The E pistle to the H ebrews: The G reek Text with Notes and Essays (repr., Grand Rapids: Eerdmans, 1977), xl. 
13:15 shows that delivering such a 'word' was customary in the synagogues: when Paul and B arnabas came to A ntioch in Pisidia, the leaders of the synagogue, following the reading of the Law and the Prophets, invited them to speak a word of exhortation to encourage the congregation. Upon that invitation Paul delivers a lengthy address about the history of I srael, concluding with the proclamation of J esus the M essiah. It is very well possible that both this sermon and the Epistle to the Hebrews follow a form of address that was customary in the synagogues. One might, then, read this letter as a sermon or homily in written form in the tradition of the Hellenistic-J ewish synagogue. ${ }^{5}$

Therefore, Hebrews as a written homily could be heard in faraway places, exhorting Christian J ews el sewhere in the world. The author, how ever, wishes to create the impression that he is in the midst of the assembled church, speaking to it directly and personally. So he carefully avoids any reference to writing or reading; instead, he accentuates speaking and listening (Heb. 2:5; 5:11; 6:9; 8:1; 9:5; see also 11:32: 'I do not have time to tell about ...'). As a preacher living at great distance from the addressees, he speaks to these Christians as if he sees them. He does so by using the first-person plural 'we' and 'us', also conveying the sense of solidarity with them. He frequently uses rhetorical devices as well. Last but not least, the dynamic within his homily is enhanced by regularly alternating instructive explanations with admonitory exhortations.

\subsection{Shift in Thinking}

By means of frequent and sometimes extensive quotations, the author endeavours to let Scripture speak. Occasionally he even gives Scripture, as it were, a direct voice by writing: 'the Holy Spirit says ...' He introduces the letter with a catena of Bible references (a series of quotations strung together like beads on a string), showing that M oses has been superseded by J esus, to whom - according to Psalm 8 - everything is subjected. A fter that, three great themes follow. These themes are characteristic and non-negotiable for orthodox J udaism: homeland, temple and city. ${ }^{6}$ Time and again, the author reminds his readers not to fix their eyes on earthly things but on things in heaven. Such a change in focus requires an upward and forward shift in the believer's thinking. In this context, he addresses all three themes:

1. The 'promised land' is the eschatological rest, which we must still enter. When Psalm 95 recounts the message for the unbelievers in the wilderness, that they would never enter the Promised $L$ and, it clearly indicates that God's promise of rest still stands (Heb. 4).

$5 \quad H$. Thyen, Der Stil der jüdisch-hellenistischen Homilie (Göttingen: Vandenhoeck \& Ruprecht, 1955; J. van Eck, Handelingen: De wereld in het geding (CNT; K ampen: K ok, 2003), 284.

6 Walker, J esus and the Holy City, 201-226. 
2. Our 'tent of meeting' is the heavenly sanctuary, where Christ ministers as our perfect high priest. He is a priest forever, in the order of M elchizedek (Ps. 110). He is the M ediator of a new covenant, one that causes the earlier one to be forgotten (J er. 31). He is the One who is to come, the One who will not delay, the One who will save the righteous by faith (Hab. 2).

3. The 'city' we look for is the city of the future, the heavenly J erusalem. God the Father at times nurtures his children with discipline - according to Proverbs 3. The trials of this life are part of the training school of faith. They should not discourage us.

This shift in thinking challenges the readers of Hebrews to stop orienting themselves on the Jewish securities. It seems that the author wants to get the following message across to them: Prepare yourselves for the loss of the earthly Jerusalem, the holy temple city. A s perilous as the situation may become - land, temple and city do not fall in the category of non-negotiable things. We can give them up. Our security is the very Son of God, J esus the M essiah. A s mediator, he is superior to M oses. Those who, in times of crisis, orient their lives around him, will find the courage to leave the camp, to let go of their dearly-held J ewishness, and to leave J erusalem. For here we do not have an enduring city, but we are looking for the city that is to come (cf. H eb. 13:13-14). Indeed, only J esus Christ will be the same forever (Heb. 13:8).

\subsection{Review}

We have seen that the E pistle to the Hebrews is a written sermon to J ewish Christians. It is an earnest appeal, exhorting them to persevere in the Christian faith. The purpose of this letter is to encourage these believers in a time when dearly held truths change and are even superseded. This watershed change, however, should not wash their certainty and courage away. On the contrary, the author exhorts 'his listeners' to cast the anchor of Christian hope into heaven, where Jesus Christ is, the embodiment of our New Testament worship. They should not drift away from him!

The following table may assist in understanding Hebrews' content and aim. The chapter divisions and the Scripture references are linked to the three great themes of homeland, temple and city. 


\begin{tabular}{|c|c|c|c|}
\hline Theme & Chapter & Represents & Scripture References \\
\hline \multicolumn{3}{|c|}{ Jesus is a Mediator superior to Moses (Chapters 1-2) } & $\begin{array}{l}\text { [Chain of references] } \\
\text { Psalm } 8\end{array}$ \\
\hline Homeland & Chapters 3-4 & Eschatological rest & Psalm 95 \\
\hline Temple & Chapters 5-10 & Heavenly sanctuary & $\begin{array}{l}\text { Psalm } 110 \\
\text { Jeremiah } 31 \\
\text { Habakkuk } 2\end{array}$ \\
\hline City & Chapters 11-13 & City of the future & Proverbs 3 \\
\hline
\end{tabular}

\section{$3 \quad$ MAIN FOCUS OF THE LETTER}

\subsection{Theme of the Sermon}

What can be considered to be the main focus of the letter? The theme of this 'sermon to the Hebrews' is: Jesus Christ, the superior high priest. ${ }^{7} \mathrm{He}$ is the fulfilment of the law and the prophets. God made him superior to M oses and A aron, superior to the Old Testament prophets and even superior to the angels. On earth, he accomplished the purifications for sins (Heb. 1:3). In heaven he now ministers as our great high priest. Therefore, every Christian needs to obey him and persevere in faith.

In the Epistle to the Hebrews the Son is for the first time called high priest precisely in connection with his reconciling work according to $\mathrm{G}$ od's plan of sal vation. The gospels and the book of Acts speak about different high priest(s) within Judaism. However, God's Son is unique. 'For this reason he had to be made like his brothers in every way, in order that he might become a merciful and faithful high priest in service to God, and that he might make atonement for the sins of the people. B ecause he himself suffered when he was tempted, he is able to help those who are being tempted' (Heb. 2:17-18).

7 The theme of the priesthood of J esus C hrist according to H ebrews has been dealt with extensively in secondary literature. See e.g.: D. R. A nderson, The K ing-P riest of P salm 110 in H ebrews (N ew York: Lang, 2001); R. B auckham, D. Driver, T. Hart and N. M CD onald, eds., The E pistle to the Hebrews and Christian Theology (Grand Rapids: Eerdmans, 2009), 229-277; K. Bensel, 'Die M elchisedek-Typologie in Hebräer 7,1-28: I hre Beziehung zu kontemporären M elchisedekTraditionen und den Prinzipien jüdischer Schriftexegese' (Ph.D. diss., ETF Leuven, 2005); M . E. Isaacs, Sacred Space: An Approach to the Theology of the E pistle to the Hebrews (Sheffield: Sheffield Academic Press, 1992), 127-178; B. Lindars, The Theology of the Letter to the Hebrews (Cambridge; Cambridge University Press, 1991), 58-100; J. M. Scholer, Proleptic Priests: Priesthood in the E pistle to the H ebrews (Sheffield: Sheffield Academic Press, 1991). C. J . den Heyer, J esus and the Doctrine of the Atonement: B iblical Notes on a Controversial Topic (Valley Forge: Trinity, 1998), minimises the theological contribution of Hebrews by stating that the letter represents a theological view that is exceptional in the N ew Testament. 


\subsection{The Superior High Priest}

The Epistle to the Hebrews tells us that J esus the M essiah functions as high priest in the framework of a new covenant between God and his people. In which way is this covenant new? Chapters 7-10, in particular, elaborate on that question. The author himself explains what his main point is: 'The point of what we are saying is this: We do have such a high priest, who sat down at the right hand of the throne of the $M$ ajesty in heaven, and who serves in the sanctuary, the tabernacle set up by the Lord, not by man' (Heb. 8:1-2).

Thereare seven differences betw een the former and the present situation (inaugurated by the high priesthood of J esus Christ), between the old and the new covenant. The ministry of God's Son is superior on every point.

\begin{tabular}{|l|l|l|}
\hline & Old Situation & New Situation \\
\hline 1. & $\begin{array}{l}\text { Priesthood received by hereditary succession } \\
\text { (order of Aaron) }\end{array}$ & $\begin{array}{l}\text { God appointed Christ as priest (order of } \\
\text { Melchizedek) }\end{array}$ \\
\hline 2. & Priests needed to be replaced since they die & Christ always remains priest: He lives for ever \\
\hline 3. & $\begin{array}{l}\text { Priests served in an earthly sanctuary, man- } \\
\text { made }\end{array}$ & Christ entered a heavenly sanctuary, God-made \\
\hline 4. & $\begin{array}{l}\text { The high priest made atonement for the } \\
\text { people, once a year }\end{array}$ & Christ continuously stays in God's presence \\
\hline 5. & $\begin{array}{l}\text { The high priest sacrificed the blood of animals } \\
\text { for his own sins and the sins of the people }\end{array}$ & $\begin{array}{l}\text { Christ sacrifices his own blood, not for himself } \\
\text { but for the sins of the people }\end{array}$ \\
\hline 6. & $\begin{array}{l}\text { The sacrifices needed to be repeated since } \\
\text { they could never take sins away }\end{array}$ & $\begin{array}{l}\text { Christ's sacrifice is made once and for all and } \\
\text { does take sins away }\end{array}$ \\
\hline 7. & $\begin{array}{l}\text { Access to the inner sanctuary on earth was } \\
\text { forbidden }\end{array}$ & $\begin{array}{l}\text { Christ's blood gives free access to the sanctuary } \\
\text { in heaven }\end{array}$ \\
\hline
\end{tabular}

\subsection{Atonement in Hebrews}

An overview of the biblical-theological theme of 'atonement' in the Epistle to the Hebrews will show various factors. All these factors are comprised in the confession of the supremacy of Christ as high priest. The writer likes to share the truth of this confession with his readers giving them the encouragement they need. That confession is also very much his own. Hebrews, therefore, breathes a brotherly tone as the writer includes himself in what he writes by using the first-person plural. The gospel of reconciliation strengthens the bond between believers and bridges great distances. Five factors can be distinguished: an accomplished fact, a new covenant, a sacrifice to God, sealing by blood, sanctification as fruit. 


\subsubsection{An Accomplished Fact}

Jesus Christ accomplished reconciliation with God. By his atoning sacrifice he abolished sin, bringing salvation to those who are waiting for him (Heb. 9:26-28). He has obtained eternal redemption and access to the promised inheritance by his death (H eb. 9:12-15). At his return total redemption will be completed. For this complete redemption the crucial condition has been met. A tonement has been made once and for all. Since God will forgive his people's sins and lawless acts, a sacrifice for sin is no longer needed (H eb. 10:18). J erusalem is facing an accomplished fact: the great high priest is already in heaven. The atoning sacrifice, given by Jesus the Messiah, forms the apex of history, the beginning of the end. Sometimes Good Friday is called: 'the Day of A tonement of the new covenant' - not without reason.

\subsubsection{A New Covenant}

In Hebrews J esus Christ is called the Surety or Mediator of a new or better covenant (Heb. 7:22; 8:6; 9:15; 12:24; found elsewhere in the New Testament only in Gal. 3:19; $1 \mathrm{Tim} .2: 5)$. He functions as an indispensable guarantee for the relationship between God and man. $\mathrm{He}$ is at the same time a personal link in that relationship. A new phase has begun through the fact that God's own Son came into the world and entered heaven after he had finished his work. His ministry as high priest bears an astounding exalted character. In comparison to his supreme ministry the whole of the Old Testament cultic worship, including the levitical priesthood, is outdated (Heb. 8:13; which of course does not mean failure). Here outdated or obsolete means that the covenant of Sinai has seen its best days. It proved to be far from perfect since the $L$ ord had to rebuke his people because of disobedience (Heb. 8:7-8a). Hence, God deemed it necessary to reorder his relationship with his people. He instituted a new covenant precisely as the prophet Jeremiah had announced (Jer. 31:31-34). The new covenant is better because God's old promises have now received a firmer foundation through the atoning death of Jesus Christ (Heb. 8:6). His death marks a new period in the relationship between God and man: the Christian era. The blood of J esus Christ is not at all the blood of a martyr. It surely does not call for vengeance but for forgiveness (Heb. 12:24).

\subsubsection{A Sacrifice to God}

A ccording to Hebrews, Christ's death on the cross can be characterized as follows: he took it willingly and once-for-all; it was voluntarily and unrepeatable. Those two aspects complement one another. He offered himself, giving the sacrifice of his life once for all (Heb. 7:27). He appeared only once to do away with sin (Heb. 9:26). His voluntary sacrifice in God's service was extraordinarily effective. He offered himself unblemished to God. Through his blood we are cleansed and consecrated for God's service (Heb. 9:14). In this verse the words 'to God' indicate the particular purpose of this sacrifice. By his voluntary death Jesus Christ dedicated himself as an acceptable 
sacrifice to God. His glorification in heaven, then, clearly proves that God accepted this unique sacrifice. Jesus obediently did God's will and fulfilled it as this was written about him in the scroll (Heb. 10:5-7; Ps. 40:5-7). Indeed, in the Old Testament his messianic obedience was plainly foretold by the prophets. Now, that he voluntarily and for once took his death did not remain without effect. For, in his divine counsel unto salvation, God had decreed that we once and for all would be sanctified through the sacrifice of the body of J esus Christ (Heb.10:10).

\subsubsection{Sealing by Blood}

In Hebrews, the blood of J esus Christ points to the surrender of his life unto death. His sacrifice has a cleansing and purifying effect. So his blood has much more power than that of rams and bulls which flowed in the temple at Jerusalem. Thanks to Jesus' blood, believers can now enter God's sanctuary with a good conscience (Heb.10:19). The blood of the covenant has sanctified them. No one should despise that blood or deem it unholy (Heb. 10:29). The people who do that will bring God's judgment upon themselves. Considering that the suffering Christ had to bear the disgrace outside the gate, one can say that he has sanctified his people by his own blood (Heb. 13:12). Because his blood is the blood of an eternal covenant, J esus can be called the great Shepherd of the sheep (Heb.13:20).

\subsubsection{Sanctification as Fruit}

According to Hebrews the supremacy of Christ as high priest bears great significance for the personal relationship with God. For sure he is merciful and faithful. With fondness, then, he gives the sheep of God's flock a place in his gentle heart. He will never break the bond with them but al ways be at hand. They may experience his aid, not the least in a time of crisis (Heb. 2:17-18; 4:15-16). Sanctification of Christian life is a fruit from his atoning messianic work (Heb. 10:10). Who, then, will benefit from this fruit? All those who are called by God and obey God's Son will enjoy the fruit of a holy life. Christ indeed has become the source of eternal salvation for all who obey him (Heb. 5:9). Certainly all those who are called will receive the eternal inheritance by his death (Heb. 9:15).

\subsection{Jesus Christ is Always the Same}

Being overwhelmed by the atoning sacrifice of the superior high priest, having established reconcilation between $\mathrm{God}$ and man, the author of Hebrews likes to tell himself and his readers in 10:22-23: ' ... let us draw near to God with a sincere heart in full assurance of faith, having our hearts sprinkled to cleanse us from a guilty conscience and having our bodies washed with pure water. L et us hold unswervingly to the hope we profess, for he who promised is faithful.' D espite the remaining introductory issues, this earnest appeal given as encouragement to persevere in the Christian faith continues to be very relevant for all those who confess the name of the Lord. J esus C hrist is the same yesterday and 
today and forever (Heb. 13:8). Seen in this way, he is the main focus of the Epistle to the Hebrews.

\section{CHRISTIAN LIFE IN THE LETTER}

In the E pistle to the Hebrews, J ew ish Christians are exhorted to set their hope on a better homeland, temple and city because of the atoning sacrifice by a better high priest, Jesus Christ. Faith in him and a life in the new covenant require a holy life - ethics. Faith and the new covenant should also stimulate a preaching with a missionary focus - mission. E thics and mission cannot be separately viewed. They are very much intertwined.

Though the basis of this letter's instruction is Christological, it nevertheless has a two-pronged approach: to ethics and mission. The author also exhorts his readers to remain faithful on that terrain. So from section 3 it is very important to observe that ethics and mission are grounded and connected to Christ's work.

Admittedly, one would not immediately think of consulting the Epistle to the Hebrews on mission. Most would think of this letter as solely concerned not with the church's relationship to the world but with internal church matters. ${ }^{8}$ W hile indeed this letter first and foremost is an intra-ecclesiastical document, it nevertheless touches on the lifestyle and witness of the believers. The manner in which they deal with their dayto-day circumstances would not and should not have escaped the attention of others.

\subsection{Spoken to by God}

The Epistle to the Hebrews begins by stating that God is speaking to us today (Heb. 1:1-4). ${ }^{9}$ As seen earlier, by using the first-person plural the author identifies himself with his readers. Those are J ewish Christians, who are descendants of the forefathers to whom in the past God has spoken by the prophets. Now he speaks to 'us' by his Son. That speaking is exceptionally rel evant for the readers. In the text the object is missing: the Son is the messenger and the message at the same time. J esus Christ is the speaking God. He is the decisive and the last Word. Being the Son, he is seated at the right hand of God in heaven.

God is the Living One (Heb. 3:12; 9:14; 10:31; 12:22); hence his speaking remains relevant for Christian life. 'For the Word of God is living and active. Sharper than any double-edged sword, it penetrates even to dividing soul and spirit, joints and marrow; it judges the thoughts and attitudes of the heart' (Heb. 4:12). The stubborn conduct of the

8 A. J. Köstenberger, 'M ission in the General Epistles,' in: Mission in the New Testament: An Evangelical Approach (ed. W. J. Larkin Jr. and J. F. Williams; Maryknoll: Orbis, 1998), 189-206 [193].

9 See on this motif: P. T. O'Brien, 'God as the Speaking God: 'Theology' in the Letter to the Hebrews,' in 'U nderstanding the Times': New Testament Studies in the $21^{\text {st }} \mathrm{C}$ entury, F estschrift for D. A. Carson (ed. A. J. Köstenberger and R. W. Yarbrough; Wheaton: Crossway, 2011), 196-216. 
people of Israel, therefore, is an 'example of disobedience', according to the author; it should not be followed (H eb. 4:11). It would be a mark of shame for the readers to fail to enter into God's rest, since it would reveal their distrust and disobedience, instead of courage and justice, two cardinal virtues in antiquity. ${ }^{10}$

Chapter 11 in contrast gives many examples of the obedience of faith of believers from the past. A prime and appealing example is Abel. He is the first witness and also the first martyr of faith. The writer says about him: 'And by faith he still speaks, even though he is dead' (Heb. 11:4). He was murdered by his own brother Cain. His blood is calling for vengeance. Y et the atoning blood of J esus, the M ediator of a new covenant, is more precious: Chapter 12 speaks about 'the sprinkled blood that speaks a better word than the blood of A bel' (Heb. 12:24).

\subsection{Good Courage and Confidence in Persecution}

The Jewish Christians, addressed in this letter, did not live in isolation from their intolerant environment. Because they had accepted Christ as their Saviour they often were publicly disgraced and humiliated, becoming a spectacle to others. 'Sometimes you were publicly exposed to insult and persecution; at other times you stood side by

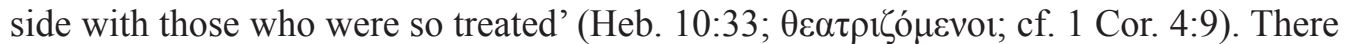
was at least an element of public humiliation in their persecution. ${ }^{11}$ The believers had accepted these sufferings. They also supported one another in their hardships. They sympathised with those in prison and joyfully accepted the confiscation of their property, because they knew that they had better and lasting possessions (H eb. 10:34; the majority text adds: 'in heaven'). In Hebrews 10:38-39 two contrasting attitudes are mentioned: 'to shrink back' or 'to believe'. Quoting Habakkuk 2 the author emphasizes the point that faith needs to show perseverance. Believers are confident that nothing whatsoever will separate them 'from the love of God that is in Christ J esus our Lord' (Rom. 8:39). Often the confidence of persecuted Christians is observed by others, who are amazed about their courage. ${ }^{12}$

The passage of Hebrews 10:19-39 (by the NIV entitled as a call to persevere) is encompassed by the term $\pi \alpha \rho \rho \eta \sigma i \alpha$ (in the NIV translated with 'confidence': Heb. $10: 19 ; 10: 35)$. In the book of Acts the same term characterizes the confident courage with which the apostles act in different circumstances. It is one of the keywords,

10 D. A. DeSilva, Perseverance in Gratitude: A Socio-Rhetorical Commentary on the Epistle 'to the Hebrews' (Grand Rapids: Eerdmans, 2000), 169.

11 H. W. A ttridge, The E pistle to the Hebrews (Hermeneia; Philadel phia: Fortress, 1989), 299.

12 K östenberger, ' $M$ ission in the $G$ eneral E pistles,' 199 says: 'The writer's exhortation to believers to go to J esus "outside the camp" and to bear suffering with him accentuates the call to Christians to be "outsiders", choosing not the easy road of material prosperity but the path of the cross, of self-denying, death-defying discipleship and, if called for, social ostracism.' 
connected with the missionary activity that is carried out with all boldness and without hindrance (A cts $2: 29 ; 4: 13 ; 4: 29,31 ; 28: 31) .{ }^{13}$ In Hebrews we are concerned with the same courageous attitude, yet here it is strengthened by the confidence of drawing near to God. 'Here it is, so to say, the content of the Christian attitude in the world, the security of God's salvation and the open confession amidst of [sic] opposition... In the situation in which the Christians live, they need it as a gift and a task.' ${ }^{14}$

\subsection{Peace with All Men}

In Hebrews 12:14 we find a fundamental rule in Christian ethics: 'Make every effort to live in peace with all men and to be holy; without holiness no-one will see the L ord.' ${ }^{15}$ Here the first element of this verse concerns the relationship with the neighbour; the second element concerns the relationship with God. Christians are peacemakers. They devote their lives unto service of the Holy One. This text seems to allude to the Sermon on the M ount: Blessed are the pure in heart, the peacemakers, for they will see God (M att. 5:8-9). ${ }^{16}$

In Hebrews 13:1-6 this fundamental principle is applied by emphasizing the following: to show mutual love and hospitality; to remember those in prison and those who are mistreated; to show fidelity in marriage and to fight against the love of money. Dependence on God in faith will only enable us to live in peace (toward the neighbour) and in holiness (toward God).

The believers need to support each other like the first Christians did in Jerusalem

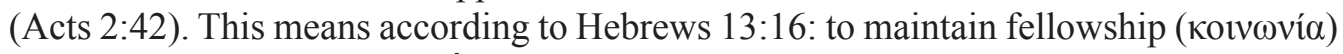
and to practise charity ( $\varepsilon \dot{\pi} \pi$ otî $\alpha$ ). Since the time of sacrificing according to the old order in J erusalem has past (Heb. 13:9), the New Testament believers need to bring 'living sacrifices that are pleasing to God' (cf. Rom. 12:1), as the writer of Hebrews says in chapter 13:16: 'And do not forget to do good and to share with others, for with such sacrifices God is pleased.' Commenting on this text, Ellingworth observes that in the Septuagint the verb $\varepsilon \dot{\alpha} \alpha \rho \varepsilon \tau \varepsilon \varepsilon \tilde{v}$ is not used in relation to sacrifices, but almost always in

13 Cf. W. C. van Unnik, 'The Christian's Freedom of Speech in the New Testament,' in Sparsa Collecta (Leiden: Brill, 1980), 2: 269-289 [279].

14 Van Unnik, 'The Christian's Freedom of Speech,' 286-287.

15 A ttridge, The Epistle to the Hebrews, 367 reads this 'all' as denoting one's fellow Christians ('inner-communal harmony'). It is more probable, however, that the author promotes peaceful relations with one's non-Christian neighbours (cf. Rom. 12:18; 1 Pet. 3:11): in this reading, 'all' really means 'all people'.

16 Cf. F. F. Bruce, The Epistle to the Hebrews (rev. ed.; NICNT; Grand Rapids: Eerdmans, 1990), 348. 
regard to people, who are pleasing generally to God (Enoch, mentioned in Heb. 11:5-6, and N oah). ${ }^{17}$

$\mathrm{H}$ aving come to the end of his letter, the author expresses this wish: may the God of peace ... 'equip you with everything good for doing his will...' (Heb. 13:20). This prayer contains an implicit exhortation. ${ }^{18}$ The Epistle to the Hebrews does not indicate if such a Christian lifestyle would lead to having a good reputation and would lead to growth of the congregation as that happened with the first Christians in Jerusalem.

\subsection{Care for Each Other}

The Epistle to the Hebrews deals also with mutual pastoral care and attention. Christians need each other. In this letter giving that spiritual help is expressed by the verb $\pi \alpha \rho \alpha \kappa \alpha \lambda \varepsilon \tilde{i}_{v}$ (admonish, encourage). Yes, we are our brother's keepers, unlike what Cain scornfully said regarding $A$ bel (Gen. 4:9). In Hebrews 3, the bad example of the disobedient generation in the wilderness is applied to each congregation member individually. A dded to that admonition is the positive appeal to encourage one another from day to day: 'See to it, brothers, that none of you has a sinful, unbelieving heart that turns aw ay from the living God. B ut encourage one another daily... so that none of you may be hardened by sin's deceitfulness. We have come to share in Christ if we hold firmly till the end the confidence we had at first' (Heb. 3:12-14). Since the believers are on the way to God's glorious kingdom, that spiritual support should be daily practice.

We also find the term $\pi \alpha \rho \alpha \kappa \alpha \lambda \varepsilon \tilde{v}$ in Hebrews 10:24-25: 'A nd let us consider how we may spur one another on towards love and good deeds.' In this text a more specific word is $\pi \alpha \rho \circ \xi v \sigma \mu$ ó $\varsigma$ (to sharpen). We need to keep each other sharp when it concerns love and doing good. Those activities of faith should not be missing. Coming to the assemblies of the congregation is vital for supporting each other on the way to God's kingdom. Hence the author adds this exhortation as well: 'L et us not give up meeting together, as some are in the habit of doing, but let us encourage one another - and all the more as you see the day approaching.' L ike in J ames 2:2, here for meeting together as congregation the Greek term $(\dot{\varepsilon} \pi)-\sigma v v \alpha \gamma \omega \gamma \eta$ is used. The usage of this word gives credibility to our suggestion (section 2.1) that the readers indeed are J ewish Christians. A t the same time a connotation with the bringing together of all the believers by Jesus Christ (1 Thes. 4:13-18; 2 Thes. 2:1) is made: the day of his coming is approaching. When the Christian congregation meets, mutual exhortation and encouragement take place in view of the gathering together on the final and great day. ${ }^{19}$

17 P. Ellingworth, The Epistle to the Hebrews: A Commentary on the Greek Text (NIGTC; Grand Rapids: Eerdmans, 1993), 772.

18 A ttridge, The E pistle to the Hebrews, 407.

19 Cf. Ellingworth, The Epistle to the Hebrews, 527-530; G. L. Cockerill, The Epistle to the Hebrews (NICNT; Grand Rapids: Eerdmans, 2012), 480. 
Christians will show a respectful attitude to their leaders, says the author of Hebrews, both the former leaders who have al ready passed on and the present leaders who are still actively watching over them like a shepherd over his flock. Members of the congregation do not forget those who have spoken to them 'the word of God', the first preachers of the gospel (Heb. 13:7), nor do they behave arrogantly to their actual leaders (Heb. 13:17; cf. 13:24). Instead, they show all the leaders honour and submission for Christ's sake, because they do their work in his name. The leaders have been and are role models for their Christian life, therefore believers have to remember them and to obey them in order to persevere in faith.

\subsection{A Forward Looking Life}

The Epistle to the Hebrews has a strong forward looking focus which puts all earthly realities in the right perspective. In C hapter 2-4, the author demonstrates on the basis of Psalm 95 that the Christian congregation lives toward the fulfilment of God's promise of rest for his people. That is an eternal sabbath-rest, praising and adoring God without end. In order to enter this rest one needs for example: to follow the heavenly call (Heb. $3: 1$ ); to be 'en route' to the city-to-come (Heb. 11:13-16; 13:9-14); to inherit what has been promised (Heb. 6:12; 11:39-40); to run the race as marked out (Heb. 12:1); to have the desire of coming to the heavenly Jerusalem ( $\mathrm{H} \mathrm{eb.} \mathrm{12:22-24).} \mathrm{The} \mathrm{Christian} \mathrm{life}$ is a pilgrimage or journey in faith ${ }^{20}$; or as J ohnsson puts it in his article on pilgrimage in Hebrews: ' $\ldots$ the Christians of Hebrews are viewed as a cultic community on the move' ${ }^{21}$

'For here we do not have an enduring city, but we are looking for the city that is to come,' thus Hebrews 13:14. This verse is often understood as a general statement about the fragility of life, or as a view about the need to let go of earthly securities: we have only a temporary place in this world. The 'city' is explained as pointing to two things: on the one hand to the earthly world which would disappear; on the other hand to the world-to-come, which is the aim of our life's quest. ${ }^{22} \mathrm{H}$ ow ever, this interpretation is not in agreement with other statements in Hebrews about the city of the future (see section 2.3).

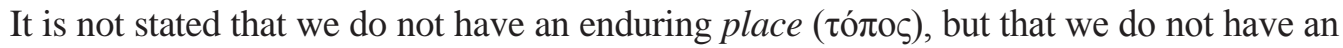

20 I. H. Marshall, New Testament Theology: Many Witnesses, One Gospel (Downers Grove: InterVarsity, 2004), 613-615.

21 W. G. Johnsson, 'The Pilgrimage M otif in the B ook of Hebrews,' J BL 97 (1978): 249.

22 Westcott, The E pistl e to the H ebrews, 442: 'T he necessity for the abandonment of the old, however dear, lies in the general fact that we have no abiding system, no unchanging organisation, in the present transitory order.' M any commentators hold this position, e.g.: B ruce, The Epistle to the Hebrews, 382; DeSilva, Perseverance in Gratitude, 503. For the Wirkungsgeschichte of this particular text, see E. Grässer, An die Hebräer (EKKNT; Zürich: Benzinger Verlag, 1997), 3: 388-389. 
enduring city $(\pi$ ó $\lambda 1 \zeta) .{ }^{23} \mathrm{~A}$ rather vague interpretation focusses on city people, implying that city life poses problems and dangers for believers. ${ }^{24} \mathrm{~A}$ ccording to Hebrews, the purpose of our life's quest is coming to the new Jerusalem. Therefore, the 'city that would not endure' is undoubtedly the old J erusalem..$^{25}$ Verse 12 speaks about Jesus' suffering 'outside the city gate' which means outside the city gate of Jerusalem. That reference is immediately followed by the call: 'L et us, then, go to him outside the camp, bearing the disgrace he bore' (Heb. 13:13). ${ }^{26}$ Jesus was deported from Jerusalem in order to be crucified outside its walls and gate. Those who join him in faith, therefore, will lose that earthly city J erusalem. The author of the E pistle to the Hebrews shares this conviction with his readers. Hence he formulates his call in the first-person plural 'we'. ${ }^{27}$

23 See P. H. R. van Houwelingen, 'Wij hebben hier geen blijvende stad,' De Reformatie 79 (2003): 49-52.

24 Cf. G. W. Buchanan, To the Hebrews: A New Translation with Introduction and Commentary (AB; New York: Doubleday, 1972), 235-236; J. C. De Young, J erusalem in the New Testament: The Significance of the City in the History of Redemption and in Eschatology (Kampen: Kok, 1960), 10; W. L. Lane, H ebrews 9-13 (WBC; Dallas: Word, 1991), 546-548. Contra F. V. Filson, 'Yesterday': A Study of Hebrews in the Light of Chapter 13 (London: SCM, 1967), 66-70; C. R. Koester, Hebrews: A New Translation with Introduction and Commentary (A B; N ew York: Doubleday, 2001), 570-571.

25 In Isaiah's prophecy of Israel's redemption, when Zion is no longer a rejected woman, then

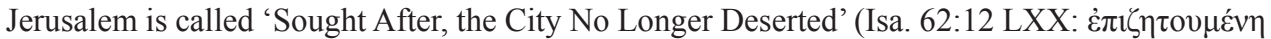
$\pi$ ó $\lambda \mathrm{i \varsigma}$ ). With great delight God's people, then, will enter her gates. We are looking for that city which is to come.

26 Here the camp is a metaphor for Jerusalem (Walker, J esus and the Holy City, 216-217). Verse 11 links this metaphor with the situation of the people of Israel during their wilderness journey; on the Day of A tonement all carcasses of the killed animals had to be burned - skin and all outside the camp. Thus Jesus let himself be slaughtered as a unique sacrifice for the complete forgiveness of all our sins (Heb. 10:1-18), outside the city gate of Jerusalem.

27 If the readers would have still lived in Jerusalem, then this call would have become very rel evant. J ews for whom J esus was the M essiah did not need to pitch their tent any longer in the camp of J ewish orthodoxy. A s followers of J esus they were prepared to give up J erusalem. That precisely happened at the siege of J erusalem by the Romans. The Christian congregation left J erusalem just before or even during the siege of the city. They took refuge outside the borders of Israel, finding a safe haven at the city of Pella in Transjordan. For further details, see: P. H. R. van Houwelingen, 'Fleeing Forward: The Departure of Christians from Jerusalem to Pella,' WTJ 65/2 (2003): 181-200. Cf. R. C. Gleason, 'The Eschatology of the Warning in Hebrews 10:2631,' TynBul 53/1 (2002): 120; Carl Mosser, 'Rahab Outside the Camp,' in The Epistle to the H ebrews and Christian Theology (ed. R. B auckham; Grand Rapids: Eerdmans, 2009), 383-404. Contra S. D. Mackie, Eschatology and Exhortation in the Epistle to the Hebrews (Tübingen: M ohr, 2007), who takes the view that Hebrews only relativises the value of Roman citizenship. 


\section{CONCLUSION}

The J ewish Christians addressed in the E pistle to the Hebrews were in danger of losing their confidence of faith. Therefore the author is strengthening this faith community so that they remain faithful. He is exhorting and encouraging them to persevere. In such a situation it is crucial to instil in them deep convictions regarding the supremacy of Jesus.

To them the preacher (indeed, the letter reads like a sermon) portrays J esus as both the model and object of faith. ${ }^{28}$ This overall observation makes it highly artificial to dichotomise between internal and external life of the church, or between ethics and mission. For genuine faith is evidenced by moral qualities, such as endurance, hope, and confidence in God's promises. These qualities have a missionary impact: they will not remain unnoticed by others. In this way, the internal dynamics of the church are indispensable prerequisites for the church's external relationships. The message for believers' activities within the community should therefore not be seen in isolation from believers' responsibilities to the outside world. ${ }^{29}$

The Epistle to the Hebrews may seem enigmatic, but what we have found gives sufficient clarity to locate this letter in the context of early Christendom. This view is warranted by many references to the cultic worship in Jerusalem. Moreover, the link with the congregation in J erusalem as suggested in the present article makes this location even likely.

So the essence of the message that this 'distance-sermon' wants to deliver, is crystal clear: faith means perseverance..$^{30}$ Indeed, this letter contains an encouraging exhortation that was designed to impact the life of the members of the congregation, internally as well as externally. Aiming to encourage believers in a time of crisis, the preacher refers his audience continuously to J esus, our heavenly High Priest. The message of the Epistle to the Hebrews is especially Christological in nature. It unleashes a dynamic interaction between ethics and mission.

\section{BIBLIOGRAPHY}

A nderson, D. R. The King-Priest of Psalm 110 in Hebrews. N ew Y ork: L ang, 2001.

A ttridge, H. W. The E pistle to the Hebrews. Hermeneia. Philadel phia: Fortress, 1989.

Bauckham, R., D. Driver, T. Hart and N. M cDonald, eds. The E pistle to the H ebrews and Christian Theology. Grand Rapids: Eerdmans, 2009.

28 V. Sung-Yul Rhee, Faith in Hebrews: Analysis within the Context of Christology, Eschatology, and Ethics (New York: Lang, 2001), 52-62.

29 Köstenberger, 'M ission,' 199.

30 Cf. H. R. van de Kamp, Hebreeën: Geloven is volhouden (CNT; Kampen: K ok, 2010). 
Bensel, K. 'Die Melchisedek-Typologie in Hebräer 7,1-28: I hre Beziehung zu kontemporären M elchisedek-Traditionen und den Prinzipien jüdischer Schriftexegese.' Ph.D. diss., ETF Leuven, 2005.

Bruce, F. F. The Epistle to the Hebrews. Rev. ed. NICNT. Grand Rapids: Eerdmans, 1990.

Buchanan, G. W. To the Hebrews: A New Translation with Introduction and Commentary. A nchor Bible. New York: Doubleday, 1972.

Carson, D. A . and D. J. M 00. An Introduction to the New Testament. 2d ed. Leicester: A pollos, 2005.

Cockerill, G. L. The Epistle to the Hebrews. NICNT. Grand Rapids: Eerdmans, 2012.

Den Heyer, C. J. J esus and the Doctrine of the Atonement: Biblical Notes on a Controversial Topic. Valley Forge: Trinity, 1998.

DeSilva, D. A. Perseverance in Gratitude: A Socio-Rhetorical Commentary on the Epistle 'to the H ebrews.' Grand Rapids: Eerdmans, 2000.

De Young, J. C. Jerusalem in the New Testament: The Significance of the City in the History of Redemption and in Eschatology. Kampen: Kok, 1960.

Ellingworth, P. The E pistle to the H ebrews: A Commentary on the Greek Text. NIGTC. Grand Rapids: Eerdmans, 1993.

Filson, F. V. 'Yesterday' : A Study of Hebrews in the Light of Chapter 13. London: SCM, 1967.

Gleason, R. C. 'The Eschatology of the Warning in Hebrews 10:26-31.' Tyndale Bulletin 53/1 (2002): 97-120.

Grässer, Erich. An die H ebräer. Evangelisch-katholischer K ommentar zum N euen Testament. Zürich, B enzinger Verlag, 1997.

Isaacs, M. E. Sacred Space: An Approach to the Theology of the Epistle to the Hebrews. Sheffield: Sheffield Academic Press, 1992.

J ohnsson, W. G. 'The Pilgrimage M otif in the Book of Hebrews.' J ournal of Biblical Literature 97 (1978): 239-251.

Koester, C. R. Hebrews: A New Translation with Introduction and Commentary. A nchor Bible. New York: Doubleday, 2001.

Köstenberger, A. J. 'Mission in the General Epistles.' Pages 189-206 in M ission in the New Testament: An Evangelical Approach. Edited by W. J. Larkin J r. and J. F. Williams. M aryknoll: Orbis, 1998.

L ane, W. L. Hebrews 9-13. W BC. Dallas: Word, 1991.

Lindars, B. The Theology of the Letter to the Hebrews. Cambridge: Cambridge University Press, 1991.

M ackie, S. D. Eschatology and Exhortation in the Epistle to the Hebrews. Tübingen: M ohr, 2007.

M arshall, I. H. N ew Testament Theology: M any Witnesses, O ne G ospel. D owners Grove: InterVarsity, 2004.

M osser, C. 'Rahab Outside the Camp.' Pages 383-404 in The Epistle to the Hebrews and Christian Theology. Edited by R. Bauckham, D. Driver, T. Hart and N. M CDonald. Grand Rapids: Eerdmans, 2009.

O'Brien, P. T. 'God as the Speaking God. 'Theology' in the Letter to the Hebrews.' Pages 196-216 in 'U nderstanding the Times': New Testament Studies in the $21^{\text {st }}$ Century, F estschrift for D. A. Carson. Wheaton: Crossway, 2011. 
Rhee, V. Sung-Yul. Faith in Hebrews: Analysis within the Context of Christology, Eschatology, and Ethics. New York: Lang, 2001.

Scholer, J. M. Proleptic Priests: Priesthood in the Epistle to the Hebrews. Sheffield: Sheffield A cademic Press, 1991.

Thyen, H. Der Stil der jüdisch-hellenistischen H omilie. Göttingen: Vandenhoeck \& Ruprecht, 1955.

Van de Kamp, H. R. H ebreeën: G eloven is volhouden. Commentaar op het N ieuwe Testament, Derde Serie. Kampen: Kok, 2010.

Van Eck, J. Handelingen: De wereld in het geding. Commentaar op het Nieuwe Testament, Derde Serie. Kampen: Kok, 2003.

Van Houwelingen, P. H. R. 'Wij hebben hier geen blijvende stad.' De Reformatie 79 (2003): 49-52.

- - - ' 'Fleeing Forward: The Departure of Christians from Jerusalem to Pella.' Westminster Theological Journal 65/2 (2003): 181-200. Cited 15 January 2013. Online: http://www. biblicalstudies.org.uk/pdf/wtj/62-2_181.pdf.

- - - . 'Riddles around the L etter to the Hebrews.' F ides Reformata 16/2 (2011): 151-162. Cited 15 January 2013. Online: http://www.biblicalstudies.org.uk/pdf/fr/16-2_151.pdf

Van Unnik, W. C. 'The Christian's Freedom of Speech in the New Testament.' Pages 269-289 in vol. 2 of Sparsa Collecta. Leiden: B rill, 1980.

Walker, P. W. L. J esus and the Holy City: New Testament Perspectives on J erusalem. Grand Rapids: Eerdmans, 1996.

Westcott, B. F. The Epistle to the Hebrews: The Greek Text with Notes and Essays. Repr., Grand Rapids: Eerdmans, 1977. 